\title{
How fear of crime affects punitive attitudes
}

\author{
Andreas Armborst ${ }^{1}$ \\ Published online: 9 June 2017 \\ (C) The Author(s) 2017. This article is an open access publication
}

\begin{abstract}
This article investigates different types of fear of crime as predictors for punitive attitudes. Using data from a Germany-wide representative survey $(n=1272)$ it examines the reliability and validity of survey instruments through confirmatory factor analysis (CFA) and uses structural equation modeling (SEM) to explain variations in the level of respondents' punitive attitudes. The results show that different emotional and cognitive responses to crime have a distinctive effect on the formation of punitive attitudes. These effects vary significantly depending on socio-demographic factors and assumed purposes of punishment. A crucial observation of the study is that men's fear of crime works in a different way in the formation of punitive attitudes than women's fear of crime. The perceived locus of control for the crime threat is a possible explanation for this difference.
\end{abstract}

Keywords Fear of crime $\cdot$ Punitivity $\cdot$ Punitiveness $\cdot$ Punitive attitudes $\cdot$ Public opinion $\cdot$ Crime policy Purposes of punishment $\cdot$ SEM $\cdot$ CFA Index construction · Survey Emotion and cognition - Risk perception

\section{Introduction: aim of the study ${ }^{1}$}

This paper examines the influence of different types of fear of crime on the formation of punitive attitudes in the German population. Although previous studies have examined this relationship, their results are inconsistent (Chiricos et al. 2004). This study examines in more detail how fear of crime influences punitivity depending on other predictors such as gender, education, age, and assumed purposes of punishment. This research applies structural equation

\footnotetext{
${ }^{1}$ This research was funded by the German Research Foundation (DFG) with the reference SA 165/40-1. I want to thank the anonymous reviewers for giving excellent and helpful feedback to this manuscript. Parts of the results of this paper have been published previously in the German language (left out for review 2014).
}

Andreas Armborst

andreas.armborst@bmi.bund.de

1 National Center for Crime Prevention (NZK), c/o German Federal Ministry of the Interior, Graurheindorfer Straße 198, 53117 Bonn, Germany 
modeling (SEM) to better understand the interplay between attitudes and sentiments toward crime and criminal offenders.

Punitivity (also known as punitiveness) is an abstract and multi-layered phenomenon that appears not only in the form of individual attitudes and emotions but also institutionally (police, judiciary, penal system) and in law-making. Hamilton (2014) refers to this distinction as individual/public opinion toward punishment on the one hand and "state or systemic punitiveness" (p. 3.22) on the other. This study focuses on the former with the intention that its results contribute to more holistic research on punitivity, including its relation with fear of crime at the micro and macro level.

Fear of crime and punitivity are the object of a public discourse that shapes the criminal policies of many Western countries (Zimring and Johnson 2006). As emotions play an important role in criminal justice (Karstedt 2002, Karstedt et al. 2011) scholars in criminology have carried out empirical research on the question of how both concepts are interrelated (Baker et al. 2015, Costello et al. 2009, Qi and Oberwittler 2009, King and Maruna 2009, Kury 2008, Messner et al. 2006).

Following this line of research this study investigates, with a multivariate methodology, whether different emotional and cognitive responses to crime operate in distinct ways in the formation of punitive attitudes. More specifically it tests whether:

(1) anger about crime has a different impact on punitivity than fear of crime

(2) social fear of crime has a different impact on punitivity than individual fear of crime.

(3) cognitive fear of crime has a different impact on punitivity than social and individual fear of crime.

Fear of crime does not deterministically lead to punitivity, but is moderated by other factors. Therefore, the study also investigates how emotional pathways to punitivity differ between different social groups and in regard to the assumed purposes of punishment.

Studying how fear of crime affects punitive attitudes is the primary purpose of this study. A secondary objective of this article is to further develop the methodology for the study of crimerelated emotions. This is necessary because empirical measures for punitive attitudes lack a canonical methodology (Adriaenssen and Aertsen 2015). In other words, to date, we do not know "whether we actually measure punitivity when we are measuring punitivity" (Sessar 2010: 368).

\section{Previous research on punitivity and fear of crime}

Research found that socio-demographic factors are generally not very good predictors for punitive attitudes (Hough et al. 2013, 24, Payne et al. 2004, 197, Windzio et al. 2007; 59; Spiranovic et al. 2011). Studies therefore focused on alternative explanations for punitivity, such as justifications for sentencing (Payne et al. 2004), fear (Dowler 2003) and anger (Johnson 2009) about crime. Building on the results of previous research into fear of crime and punitivity this study investigates how different cognitive and emotional experiences of crime are linked to punitive attitudes, and how these links vary depending on other known predictors of punitivity such as gender, age, education, and assumed purposes for sentencing.

Fear of crime and punitivity have been studied extensively both in theory and empirically, but less is known about the relation between the two concepts. Some studies conclude that 
people who are afraid of crime are more likely to express punitive attitudes than people who are not afraid of crime (Windzio et al. 2007; 59, Langworthy and Whitehead 1986; Costelloe et al. 2002; and Dowler 2003), whereas others found mixed results (Kury and Winterdyk 2013) or no such relation (Kleck and Jackson 2016, King and Maruna 2009: 160). Tyler and Boeckmann (1997) concluded that "the widely held view that public punitiveness develops primarily from concerns about crime [...] and public views about risk and dangerousness, is incorrect." Given this inconsistent picture this study examines the link between fear of crime and punitive attitudes in greater detail.

Besides fear, other emotions have been discussed as a potential source of punitivity: "Crime policies are explicitly based on the expression of collective emotions of fear and anger about crime" (Karstedt 2002: 3). Following Johnson (2009) who demonstrated that anger about crime is a robust predictor of punitivity this article seeks to clarify how fear and anger operate together in the formation of punitive attitudes.

\section{Punitivity}

Punitivity describes an abstract and complex social phenomenon that includes not only individual attitudes, sentiments and emotions but also, more generally, a particular style in which society as a whole (legislation, judiciary, police, penal system, media and public opinion) reacts to criminal behavior (Garland 2000, 2001). ${ }^{2}$

The present study focuses on punitive attitudes alone, and measures their extent and origin using a questionnaire instrument. In accordance with many other authors, Windzio et al. (2007: 13) define punitive attitudes as "the propensity of people to impose on the offender retributive justice rather than reconciliatory or compensatory settlements" (Windzio et al. 2007: 13). However, the operationalization of punitivity in survey research is fraught with a number of difficulties since many studies could not clarify whether the varying opinions on criminal sanctions do indeed represent a coherent single concept (Adriaenssen and Aertsen 2015).

Opinion research has used numerous indicator variables to measure punitive sentiment, such as questions on the adequacy of criminal penalties for certain offenses, opinions about alternatives to criminal punishment, penal legislation - for example three strike laws - , and criminal prosecution by the police and the judiciary (Hogan et al. 2005, 399; Hough et al. 2013, 24; Applegate et al. 1996). Questions about respondents' attitude toward the death penalty (Reuband 1980) are sometimes referred to as the "standard item for punitivity" (Kury and Obergfell-Fuchs 2008: 234).

The academic discourse about punitivity is as much a methodological one as it is a discourse about the phenomenon itself. This raises the question whether punitivity might be an academically overloaded concept that attracts a lot of scholarly attention despite the fact that it is a relatively indistinct attitudinal pattern which is consequently hard to measure. A secondary objective of this study, therefore, is to test the assumption that people indeed express a coherent attitude pattern in response to a series of survey questions that are supposed to measure punitivity, and which can be summarized in a single measurement index.

Several studies use different indicator variables to build a measurement index (Chiricos et al. 2004: 369; Hartnagel and Templeton 2012: 460; Hogan et al. 2005: 399; Hirtenlehner 2011: 37; Johnson 2009; Kury and Obergfell-Fuchs 2008: 242; Windzio et al. 2007: 45, Hough et al. 2013:24). However, few studies investigate whether the response to a series of

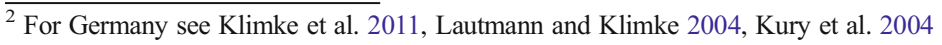


opinion questions on criminal policy really originates from a common underlying conviction (punitivity), and most of them are based on data from surveys in the US (Mascini and Houtman 2006, Pickett and Baker 2014). Because European mentalities about crime and punishment are fundamentally different, one cannot assume that these measurements are reliable in European survey research. In other words, to date, we do not know "whether we actually measure punitivity when we are measuring punitivity" (Sessar 2010: 368).

\section{Fear of crime}

In contrast, survey instruments for measuring different types of fear of crime are theoretically and methodically much more sound (Gray et al. 2008, 2012; Farrall et al. 2009). People's attitudes and emotional responses toward crime have been studied in greater detail than attitudes toward any other social problems. Although there are studies on "fear of unemployment" (Reichert and Tauchmann 2011), "fear and anxiety about diseases", such as "fear of AIDS" (Bouton and et al. 1987), or "fear of climate change" (Moser 2007), most social researchers show more interest in the response to crime. Their studies have revealed in great detail the extent and correlates of fear of crime in the population and on the individual level. The results show that crime not only evokes fear. People express emotional (fear, anger, worry) and cognitive (perception of risks) responses to crime, and in doing so discern three threatened groups (themselves, close ones, and society at large). For instance, Ditton et al. (1999: 89) suggested "that anger was both more common a response than fear and that it was more intensely felt" and Farrall tested "whether worry about crime is a 'different beast' to the perception of the likelihood of victimization" (Farrall 2004: 303).

According to the current state of research, sentiments about crime are expressed as follows:

1. affective, as fear, anger (Ditton et al. 1999), or worry (Crime survey for England and Wales) about personally becoming a victim of crime;

2. altruistically (Warr 1992: 726) or empathic (Vanderveen 2008: 43) as fear, anger, or worry that a friend or family member may become a victim of crime.

3. as social fear of crime, that is, fear, anger, or worry about crime as a social problem that threatens not the individual but society as a whole (Boers 1991: $207 \mathrm{ff} .$, Frevel 2003: 325);

4. cognitive, as a subjective assessment of the personal risk to be victimized (Farrall 2004: 303).

5. conative, as protective action.

In addition, there are different perceptions of crime as a social problem opposed to crime as a threat to the individual (Tyler and Boeckmann 1997, 246). A recent study by the Max Planck Institute shows that the concern "about the development of crime in Germany" is three times more widespread than the concern to personally become a "victim of crime" (Haverkamp et al. 2013). This study tests the assumption that both types are associated with punitivity in different ways. Furthermore, Johnson (2009) showed that anger over crime works in a different way than fear of crime in predicting individuals' level of punitivity.

Furthermore, there is sound evidence for the generalization hypothesis, which shows that people's fear of crime is not only evoked by their perception of crime itself, but also by their experiences of general fears, insecurities, and uncertainties (Hirtenlehner 2006, 2011). Poverty and lack of welfare benefits can therefore lead to fear of crime (Oberwittler 2008, Hummelsheim et al. 2011). 
Regarding the different emotional and cognitive responses to crime this paper examines how well each of them explains variances in the level of punitivity.

\section{Methodology}

The methodology section of this article describes survey design and sampling strategies as well as the construction of the two survey scales to measure punitivity and fear of crime.

\section{Sampling strategies}

Following design and cognitive pretesting, the survey instrument went into the field phase in the form of a written postal survey in July $2011{ }^{3}$ The polling institute INFAS dispatched the questionnaire to 4592 target recipients along with a personal letter containing the study background, a data protection declaration, and a pre-paid return envelope. To maximize response rate, voluntary participation in a raffle was offered with one $€ 1000$ and twenty $€ 100$ prizes. In the personal letter, the questionnaire was introduced to the recipients under the title "Security and Living Together in Germany". On 15 pages, participants were asked to give details about their fear of crime, attitudes toward criminal policy and demographic information. Until early September INFAS sent out up to two reminders and a separate letter to recipients who had not responded to the initial mailing.

To obtain a representative sample of the parent population (all persons living in private households, 18 years of age and older), INFAS conducted two sampling stages. In the first stage, 112 municipalities (primary sample points) were identified through a random sample, stratified by ten BIK size classes (probability proportional to size). In the second stage, personal addresses were sampled from within the selected municipalities (secondary sample points). The final gross sample was then determined from the records of residents' registration offices of the municipalities based on systematic random sampling (starting number and interval). The gross sample includes 4592 addresses. In 286 cases, the questionnaire could not be delivered (sampling-neutral non response). The eventually realized sample coverage was $30 \%$ (1272 cases) of the adjusted gross sample. While this is a slightly disappointing coverage rate, the effects on the representativeness are not worrisome.

In order to assess representativeness, some sample characteristics were compared with corresponding characteristics in the German microcensus of 2009. All ten municipality size classes were represented proportionally in the sample (with an average deviation of $0.6 \%$ ). Younger people, between 18 and 44 years of age (both men and women), were slightly underrepresented in the sample whereas older people, between 55 and 74 years, were slightly overrepresented compared to the parent population. The strongest sampling bias occurred in terms of formal education (middle class bias): only a quarter of respondents had a lower secondary school qualification as the highest level of formal education, while the actual proportion in the German population is $43 \%$. Accordingly, cases with higher secondary school degrees $(+8.5 \%)$ and technical college/university degrees $(+9.3 \%)$ as highest formal education degrees were overrepresented. To compensate for the described sample bias, the distribution of

\footnotetext{
${ }^{3}$ Kury and Obergfell-Fuchs (2008: 235) have shown with qualitative follow-up interviews that values for punitivity are higher in written surveys compared to oral interviews. This effect could not be quantified in our study.
} 
characteristics in the sample was fitted by weighting to the distribution in the parent population (iterative proportional fitting). This was done at the expense of the sampling error $\sigma^{2} / \mathrm{n}$ ) and the effective sample size, which was still 900 after weighting.

\section{Construction of scales for measuring punitive attitudes}

Punitivity is the dependent variable that this study seeks to explain through different dimensions of fear of crime. By means of Confirmatory Factor Analysis (CFA) it tests whether the responses from the participants can be attributed to a uniform punitive attitude pattern. CFA satisfies the frequently articulated demand for empirically validated scales to measure punitive attitudes (Simonson 2011: 90; Kury et al. 2004; Adriaenssen and Aertsen 2015).

Most punitivity indices are based on EFA and Cronbach's alpha as a statistical criteria for the internal consistency of the variables. ${ }^{4}$ However, due to the fact that a set of variables is internally consistent (i.e., that these variables correlate with each other), one cannot conclude that these variables also originate from a common factor (Schmitt 1996: 350). Many attitudes may systematically correlate with each other without having a common statistical origin that could be interpreted as a latent factor. This can only be assessed by means of a CFA. However, the possibilities of this method have not yet been fully exploited to empirically validate scales for the measurement of punitivity (a noteworthy exception is the study of Maguire and Johnson 2015).

When constructing the index variable the research team encountered a couple of unforeseen difficulties that are worth reporting because they indicate that punitivity might be a less coherent set of attitudes than generally assumed. In survey research it is often assumed a priori that punitive people consistently promote more severe punishment and by the same token reject offender rehabilitation throughout a series of different but thematically related survey questions. This assumption however is not supported through the data. Neither one, nor more-dimensional factor models yielded acceptable results. ${ }^{5}$ Explorative factor analysis (EFA) ${ }^{6}$ explained a satisfying $45 \%$ of total variance, but the four extracted factors had no common thematic ground such as punitivity against particular groups (e.g., foreigners and migrants) or particular offenses.

There seem to be two substantial reasons for the statistical inconsistencies. First, punitiveminded people do not necessarily call for more severe sentences instead of rehabilitative measures. The survey questions regarding attitudes toward rehabilitative measures (that is, more lenient forms of punishment) cannot predict whether a respondent would advocate tougher criminal policies in other matters (see also Butter et al. 2013, Mascini and Houtman

\footnotetext{
${ }^{4}$ Hirtenlehner (2011: 37) uses a scale for punitivity with three indicator variables $(\alpha=0.73)$; Chiricos et al. (2004: 369) combine eight questionnaire items into one index $(\alpha=.88)$; Windzio et al. $(2007: 44,45)$ discern three scales for punitivity with seven, three, and six indicator variables respectively. Their respective $\alpha$ are: 0.83 for the component "the advocacy of the severity of punishment, as a deterrent", 0.92 for the component "endorsement of capital punishment", and 0.68 for the component "endorsement of penal leniency" and "alternatives to imprisonment". Johnson (2009: 56, 57) uses four questions: "measuring support for three strikes law, stricter parole, trying juveniles in adult courts, and harsher penalties for violent offenders". Butter et al. 2013, and Garland et al. 2015 also use Cronbach's alpha to assess internal validity of survey scales.

${ }^{5}$ Indicator reliability of many variables is below 0.5 and the proportion of variance explained is $29 \%$ (results not shown in tables).

${ }^{6}$ Principal component analysis, oblique rotation (Promax), extraction at eigenvalue $>1$ after 25 iterations. (results not shown in tables).
} 
2006; Reuband 2007a, b: 191). Many respondents are for more severe penalties, although at the same time they are not against alternative forms of punishment.

The second reason is that the demand for tougher sanctions and law enforcement measures does not necessarily override constitutional principles (Pratt 2000, 2007). For a small proportion of respondents this is indeed true. However, the majority of respondents who reveal punitive tendencies have a more differentiated attitude. For them, constitutional principles (the rule of law) rank above their individual "desire to punish", and not vice versa - even for sexual offenses, which usually reveal punitive tendencies particularly well. Moreover, in this survey populist statements ${ }^{7}$ were much more homogeneously rejected or endorsed by the respondents than more differentiated statements. ${ }^{8}$

Finally, only 11 out of initially 25 survey items met the substantive and statistical criteria for building a punitivity index. The survey questions and the response categories are listed in Table 1. For the purpose of this study, punitivity is defined as 'the tendency of a respondent to consistently support tougher criminal policies throughout a set of survey questions concerning different topics of criminal policy' (for example tougher sentences or more rigorous prosecution). All variables were tested for univariate and multivariate normal distribution. Critical ratio is used as a measure for multivariate skewness. ${ }^{9}$ Since the distribution of many variables is skewed (which is particularly the case for variables that measure fear of crime) asymptotically distribution-free test (ADF) is preferable to standard maximum likelihood estimation (MLE) as the estimation procedure for calculating the free parameters in the structural equation model (SEM) (Browne 1982, 1984; Wothke 1993: 264 f., Raykov and Marcoulides 2006: 30). Tables 1, 2, and 3 show the 11 indicator variables, the results of the CFA and the frequency distribution of the newly derived index.

Evaluation and modification The results of the CFA include a couple of metrics that evaluate the quality of the measurement index (Bagozzi 1981). Local measures of goodnessof-fit give information about the suitability of individual components of the model, while global measures of goodness-of-fit estimate how well the postulated model represents the empirical data in general. Again it is worth reporting and commenting on these metrics because they contribute a great deal to the consistency of the punitivity concept.

Table 1 reports the local goodness-of-fit statistics, namely weighted least squares $\left(\beta^{2}\right)$ of the indicators (also called indicator reliability), the factor-, or composite reliability (CR), and the average variance extracted (AVE). The value of $\beta^{2}=.54$ (for variable V1) indicates, for example, that the latent factor (punitivity) can explain 54\% of the variance of this variable, which means that $46 \%$ of the variance is caused by unknown factors. For the weakest indicator (V11), the explained variance is still $25 \%$. Indicators with lower explained variance were not included in the index. The CR measures the internal consistency of the indicator set, similar to Cronbach's $\alpha,(\mathrm{CR}=0.88, \alpha=0.825)$. Factor reliability is however more appropriate than Cronbach's $\alpha$, because the latter is sensitive to the total number of indicators (Chin 1998: 320; Hair 2006: 777).

The average variance extracted (AVE) evaluates the convergent validity of the measurement construct. Specifically, it indicates how much of the total variance of all 11 indicators can, on

\footnotetext{
${ }_{7}^{7}$ For example: "Inmates are having a good time in German prisons"

${ }^{8}$ For example: "Torture of a suspect is not allowed under any circumstance, even if this could save innocent lives". Or: "Threat of severe punishment is useless, because it hardly deters anybody".

9 "Which in essence represents Mardia's (1970) normalized estimate of multivariate kurtosis" (Byrne 2010: 104). Values $>5.00$ indicate that data are not multivariate normally distributed.
} 
Table 1 Indicator variable

$\beta^{2}$

In general, imposed sentences for overall crime are.. 1 = way too high 5 = way too low (V1) $\quad .74 \quad .54$

Prisoners in German prisons have it too good. $1=$ totally agree $4=$ totally disagree (V2) $\quad .71 \quad .50$

$\begin{array}{lll}\text { For grave offenses, like sexual abuse of children, the death penalty would be appropriate (V3) } & .68 & .47\end{array}$

Names, photos, and addresses of released sex offenders should be made public, so that $\quad .64 \quad .41$ everyone can protect themselves. (V4)

When immigrants become criminal they should be deported, even if they have lived here $\quad .64 \quad .41$

for ten years and own a German passport. (V5)

$\begin{array}{lll}\text { If the police could get tough on crime there would be less crime. (V6) } & .62 & .39\end{array}$

In general, imposed sentences for juvenile offenders are $1=$ way too high 5 = way too low (V7) $\quad .59 \quad .35$

$\begin{array}{lll}\text { Those who commit the same offense three times should get a life sentence by default (V8) } & .58 & .34\end{array}$

In general, imposed sentences for sexual offenders are 1 = way too high 5 = way too low (V9) $\quad .55 \quad .30$

The minimum age of criminal accountability should be less than the current age of 14, so $\quad .51 \quad .26$ that children can be punished (V10)

Even sexual offenders have a right to be released after they have served, as long as $\quad .50 \quad .25$ the risk of recidivism is not high (V11)

Composite reliability (CR)

.88

Cronbach's $\alpha$

average, be explained by the common factor (punitivity). The value AVE $=0.42$ therefore means that the latent attitude pattern "punitivity" explains, on average, $42 \%$ of the total variance in the 11 indicator variables, whereas unknown exogenous factors cause $58 \%$ of this variance. This illustrates the before mentioned shortcoming of using Cronbach's $\alpha$ as the only measure to assess construct validity: a value of $\alpha=0.825$ indicates a high degree of reliability and commonality of the indicator set, but it would be wrong to assume that the commonality is caused by a common latent factor (and this is often implicitly or explicitly done. The results show that despite $\alpha=0.825$ the AVE is only $42 \%$. This means that the common factor (punitivity) explains only $42 \%$ of the high commonality of the indicator set. From the observation that a group of indicators is highly correlated with each other one cannot conclude that these indicators represent the same construct. Survey research based on EFA and Cronbach's $\alpha$ (EFA) alone, therefore, is prone to overestimation of the construct validity of punitivity scales.

The global measures of goodness-of-fit in Table 2 indicate how well the theoretically assumed model represents the empirical data overall. CFA and SEM compare an assumed correlational structure of variables against the actual (empirical) correlational structure of these variables. A frequently used criterion for this fit is the root mean square error of approximation (RMSEA). The corresponding value in Table 2, in the row "assumed model" is 0.062 , which indicates an acceptable fit of the model. The normed fit index (NFI = .779), the comparative fit index $(\mathrm{CFI}=.807)$, and chi square divided by the degrees of freedom $\left(\chi^{2} / d . f .=5,8\right)$ just miss the threshold, which means that the postulated factor model does not fit the empirical data particularly well. Something is still wrong with the punitivity index.

One way to improve the fit of the model is to use modification indices (Steiger 1990). Modification indices point to correlations between variables that are not formulated in the theoretical model but which exist in reality (figuratively speaking: in the right section of the postulated model depicted in Fig. 2, an arrow is missing between indicators where there should actually be one). Non-specified but existing correlations diminish the global fit of the model, which is why a model can be subsequently modified. However, this is 


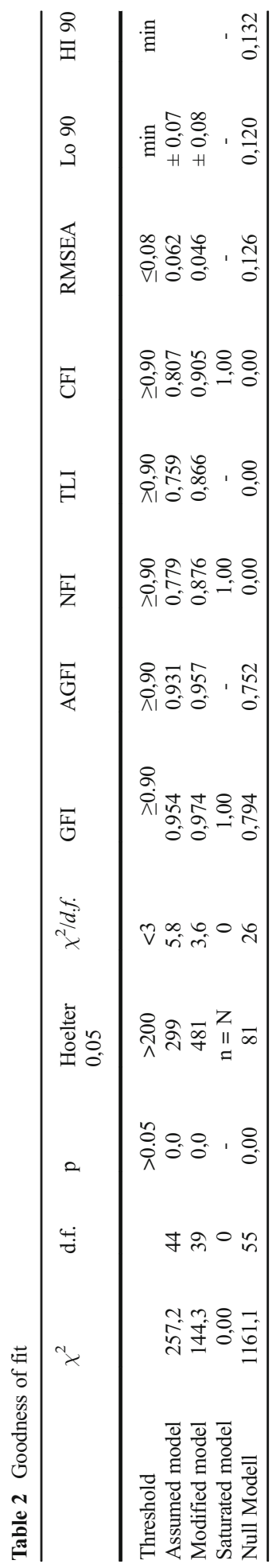


Table 3 Convergent and discriminant validity measures for 3 types of fear of crime

\begin{tabular}{|c|c|c|c|c|c|}
\hline Component & Indicator & $\begin{array}{l}\text { Indicator reliability } \\
\beta^{2}>.4\end{array}$ & $\begin{array}{l}C R \\
>.6\end{array}$ & $\begin{array}{l}A V E \\
>.5\end{array}$ & $\begin{array}{l}F-L-R \\
<1.0\end{array}$ \\
\hline Cognitive fear of crime & $\begin{array}{l}\text { Burglary (A1) } \\
\text { Robbery (A2) } \\
\text { Property damage (A3) } \\
\text { Battery/bodily harm (A4) }\end{array}$ & $\begin{array}{l}.52^{\mathrm{a}} \\
.71 \\
.55 \\
.59\end{array}$ & .85 & .59 & .59 \\
\hline $\begin{array}{l}\text { Affective fear of crime } \\
\text { (group A: offenses against } \\
\text { the individual) }\end{array}$ & $\begin{array}{l}\text { Burglary (B1) } \\
\text { Robbery (B2) } \\
\text { Property damage (B3) } \\
\text { Battery/bodily harm (B4) }\end{array}$ & $\begin{array}{l}.52 \\
.66 \\
.59 \\
.55\end{array}$ & .85 & .58 & .68 \\
\hline $\begin{array}{l}\text { Affective fear of crime } \\
\text { (group B: offenses against the } \\
\text { general public) } \\
\text { RMSEA }=.062\end{array}$ & $\begin{array}{l}\text { Corporate Crime (C1) } \\
\text { Corruption (C2) } \\
\text { Tax evasion (C3) }\end{array}$ & $\begin{array}{l}.64 \\
.69 \\
.60\end{array}$ & .84 & .64 & .62 \\
\hline
\end{tabular}

${ }^{\text {a }}$ Alle $* * *$

an intervention into the theoretical assumptions of the postulated model and therefore must be substantively justified, else the model loses its theoretical predication value and becomes utterly meaningless.

Here, the model fit affects two groups of variables: variables related to sexual (V4, V9, and V11) and to juvenile (V7 and V10) offenders (see Table 1 for wording). These variables are influenced to a small extent by an independent, exogenous factor that can simply be interpreted as a separate attitude pattern of the respondents with respect to a specific group of offenders (sexual offenders, juveniles). The exogenous factor contributes only around 5\% to the overall explained variance of the endogenous factor punitivity. This by no means justifies the construction of a second endogenous factor. However, from the theoretical point of view, the modification of the model is certainly sensible and clearly improves the global measures of goodness-of-fit (Table 2).

Based on this rigorous procedure the punitivity index (dependent variable) is built. This procedure, albeit lengthy, is necessary to avoid erroneous conclusions about the nature and extent of punitive attitudes in the German population and its relation to fear of crime. Despite all rigor we had to make some pragmatic decisions about including/excluding single measurement items. This also indicates that our survey metrics are still less than perfect and still need calibrations and testing. The scores of the index are summarized in Table 3 and will be discussed in greater detail later. The next part describes the construction of the independent index variable (fear of crime).

\section{Scale construction for measuring fear of crime}

Unlike composite measures for punitivity, scales for measuring fear of crime are much more standardized and have already been verified by CFA in previous criminological studies (Jackson 2005). To confirm the validity of the instrument this study applies CFA with a set of survey questions about different feelings toward different offenses. Of the five dimensions of fear of crime mentioned above, the survey measured affective, social, and cognitive fear of crime with the following questions (Gray et al. 2008, Ditton et al. 1999): 
1. Within the last 12 months, [how often] [how strongly] did you [fear] [did you get angry] that [your home is burglarised] [corporate crime increases] [you get robbed out of home] [people gain advantage through corruption] [your property is vandalized] [you are assaulted] [people evade taxes]. Five point scale. ${ }^{10}$

2. How likely do you think it is that within the next 12 months the following things will happen to you? [burglary] [robbery] [property damage] [bodily harm]. Four point scale.

In order to distinguish between social and individual fear of crime, item set 1 has two different groups of offenses: four offenses against the individual (burglary, robbery, wilful damage to property, bodily harm), and three offenses against the general public (corporate crime, corruption, tax evasion). These items were chosen to operationalize the different dimensions of fear of crime as used in previous research.

Another popular and validated survey item is the simple question "how safe would you feel walking at night within a mile of your home". There are numerous advantages for using the so called "standard item" in fear of crime research, especially when comparing levels in fear of crime between countries, or when investigating the social-spatial context of fear of crime (Pritsch and Oberwittler 2016). For this reason it is used, for example, in the recent German Victimization Survey with a sample of 35,000 respondents (Birkel et al. 2016). Although this item tells us a great deal about people's fear of crime it lacks more nuanced aspects about the phenomenon that might be crucial in explaining how fear of crime affects punitive attitudes.

The corresponding scale consists of five subscales with 21 indicators (1) fear and (2) anger about (3) individual victimization and (4) offenses against the general public (5) risk assessment of individual victimization. In analogy to the punitivity scale, this typology is tested with CFA before actually constructing the independent index variable. In addition to convergent validity (measured through AVE), multidimensional concepts must also meet criteria of discriminant validity. In statistical terms this means that each set of indicators must be not only internally consistent (composite reliability) but also markedly different from the other sets of indicators (discriminant validity). The results of the CFA show that with the data of this sample, discriminant validity is not achieved between the measures for fear of crime and anger about crime.

This observation is worth some reflection because it seems reasonable to believe that people's fear about crime is different from their anger about crime. This issue is also crucial in regard to the question whether fear and anger work in different ways in the formation of punitive attitudes. Figure 1 shows that there is a significant difference between anger and fear in regard to offenses against the general public but not in regard to offenses against the individual. In the latter offense category, only burglary shows a significant difference between anger $(\overline{\boldsymbol{x}}=1.6)$ and fear $(\overline{\boldsymbol{x}}=1.9)$. It also shows that respondents express systematically more fear and anger about offenses against the general public.

Finally, it is noteworthy that the overall levels of fear and anger in the population are low. In the first offense category none of the mean values are above 2.5 on the five-point scale.

Statistical significance between means is not a sufficient criterion for discriminant validity in measurement scales. Therefore, two alternative hypotheses are tested that state that responses to survey questions about the extent of fear and anger are attributable to the same

${ }^{10}$ Because the frequency and the intensity measures almost identical (collinear), both are collapsed into one variable. 


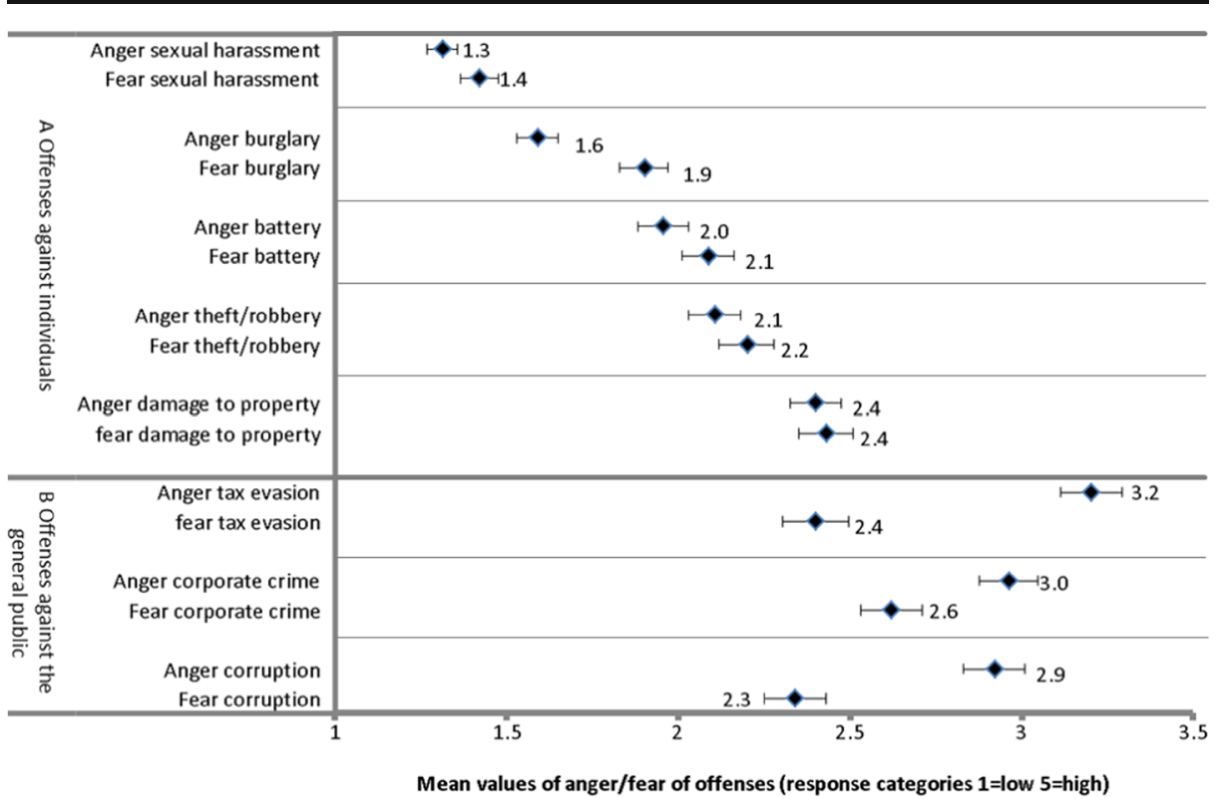

Fig. 1 Comparison of means with confidence intervals for fear of crime in regard to different offenses

factor. If this alternative hypothesis cannot be falsified, one cannot assume discriminant validity of the two factors. The alternative hypotheses are:

H1. The five variable pairs for measuring anger and fear in response to offenses in category $\mathrm{A}$, are based on a common latent factor.

$\mathrm{H} 2$. The three variable pairs for measuring anger and fear in response to offenses in category $\mathrm{B}$, are based on a common latent factor.

H1 corresponds to a 1-factor-10-indicator model with the respective five indicator pairs from offense category A. H2 corresponds to a 1-factor-6-indicator model with the three indicator pairs from offense category B. Both alternative hypotheses cannot be falsified with the data of this sample as the results suggest collinearity between the variable pairs with correlations between 0.6 and 0.7 (results not shown in tables). This means, with little exception, that the questions about fear and anger trigger exactly the same answer.

One possible explanation for this result is that, overall, the respondents expressed very little concern for crime, and thus it is difficult for them to further differentiate their weak concerns into fear and anger. ${ }^{11}$ Therefore, it is not clear what emotion they actually express when they give the identical answer to two different questions: fear, anger, or something else? It only seems safe to say, although this is a slightly trivial observation, that these are aversive feelings toward crime.

\footnotetext{
${ }^{11}$ See also Farrall (2004: 169): “These have suggested that 'fear' and 'anger' may have been over-reported and that detailed qualitative work regarding people's feelings about crime and experiences of such feelings suggest that these feelings may be less common than we think."
} 
Table 4 Quartiles of the punitivity index

\begin{tabular}{lll}
\hline Punitive attitude & Frequency & Percentage \\
slight $(0-<25)$ & 95 & $7,7 \%$ \\
slight-moderate (25-50) & 398 & $32,5 \%$ \\
moderate-high (50-75) & 503 & $41,0 \%$ \\
high (75-100) & 230 & $18,8 \%$ \\
$\mathrm{n}=$ & 1.226 & $100 \%$ \\
missing & 46 &
\end{tabular}

The next step is to examine whether at least there are distinguishable responses regarding the aversion of offenses against the individual on the one hand, and offenses against the general public on the other. Respondents systematically express more aversion against the latter, as can be seen in Fig. 1, but is this difference really attributable to a separate factor? The corresponding alternative hypothesis to this assumption is:

H3. The aversion to offenses in the offense categories A and B is caused by one common latent factor.

A 1-factor-8-indicator model operationalizes this hypothesis. The corresponding test with CFA (resulting in RMSEA $=0.113$ ) indicates that the hypothesis is not supported by the data. People's answers to the eight questions are clearly not attributable to the same factor. Instead, the first three modification indices reveal the impact of a second factor. The consequential 2factor-8-indicator model meets, as expected, all requirements for convergent and discriminant validity. $^{12}$

As a final step, questions regarding cognitive fear of crime were added as the third component of the measurement model. The corresponding alternative hypothesis (H4) was clearly rejected: affective and cognitive fear of crime are not attributable to one single factor, but are better described by a 2-factor model. The eventual composite index comprises three components and 11 indicators (see Table 4). Table 4 summarizes the parameters for convergent and discriminant validity of the CFA, and reports reliability $\left(\beta^{2}\right)$ of each indicator. All three dimensions are convergent, that is, each indicator bundle is attributable to one common factor that sufficiently explains variance (as shown by CR and AVE). Moreover, the three factors are discriminant, that is, their indicators correlate stronger within their respective factor spaces than in between them. The relevant criterion, the Fornell-Larcker ratio (FLR), measures whether the AVE of each factor is greater than the square of the maximum factor correlation in between them (Fornell, Larcker 1981). If this criterion is not met, FLR takes on values $>1$. The global model accuracy, as measured by RMSEA (=0.062), also suggests robustness of the model as a whole.

\footnotetext{
${ }^{12}$ RMSEA $=0.52$. Convergent and discriminant validity (indicator bundle of the offense group B): factor reliability $=0.83 ; \mathrm{AVE}=0.63$; Fornell-Larker-Ratio $=0.65$; all factor loads are significant at the $99 \%$ level (inmatesin table).
} 
The next section addresses the main research question, namely whether different types of fear of crime have a distinctive effect on the formation of punitive attitudes, and whether these effects are dependent on other factors.

\section{Results}

The dependent variable in the SEM is a composite index measuring the extent of punitivity in the German population. As described in the methodology section, 11 indicator variables are collapsed into a new index variable with values ranging from 11 to 47 points. ${ }^{13}$ This sum index is then transformed into a percentage of maximum possible (POMP) scale (Cohen et al. 1999). POMP indicates the percentage of maximum possible points on the scale achieved by a respondent. Compared to an additive index this has the advantage that cases that have not answered all 11 questions (item non-response) are scaled and hence can still be included in the index.

How punitive is the German population? Table 3 shows the absolute and relative frequency distribution of respondents within the four quartiles of the scale $(0-<25,26-<50,51-<75$, 76-100). The distribution has a mean of $\overline{\boldsymbol{x}}=55$ and its SD is $\boldsymbol{\sigma}=20$ points (left-skewed, negative skew). Around a quarter of the German population expresses a clear attitude pattern across all 11 survey questions; $18.8 \%$ consistently advocate tougher sanctions and therefore have high punitivity scores $(>75)$ whereas 7.7 consistently endorse more lenient sanctions and therefore score lower $(<25)$. The average punitivity score of the German population is 55 out of 100 points. There is no clear baseline to compare this value, since most studies on the German population have used different scales (Reuband 2011, Cochran and Piquero 2011). Using a similar scale, Hartnagel and Templeton (2012): 461) calculated (based on seven indicators) an average value of 67 points in the US population, also with a left-skewed distribution (median $=71 \%$ ). This is consistent with the findings of other studies that the US population is generally more punitive than the German population.

How well can different types of fear of crime explain variances of punitive attitudes? Figure 2 shows the results of the SEM. The path weights $(\beta)$ show that people's subjective risk perception (cognitive fear of crime) has no significant influence on their punitive attitudes. This is consistent with findings from a study by Baker and colleagues who found that perceived "victimization risk is only marginally significant" in explaining individual's support for rehabilitative crime policies $(2014,8)$.

Aversion to offenses against the general public affects the extent of punitivity more strongly (.18) than offenses against the individual (.13), but overall fear of crime explains only $10 \%$ of the total variance of punitivity. Apparently, the reasons for why people endorse or reject harsher punishments are more complex than that. Accordingly, four additional variables are added to the model (Table 5).

Table 5 shows four moderator variables 'purposes of punishment', sex, age, and education as well as the average scores $(\overline{\boldsymbol{x}})$ these groups attain on the punitivity index and the fear of crime index (only individual and social fear of crime). These variables were selected because other studies demonstrated their impact on punitive attitudes (e.g., Spiranovic et al. 2011). We are therefore interested to see how these predictors moderate the influence of fear of crime on punitive attitudes.

${ }^{13}$ Eight variables have four and three variables five response characteristics. 


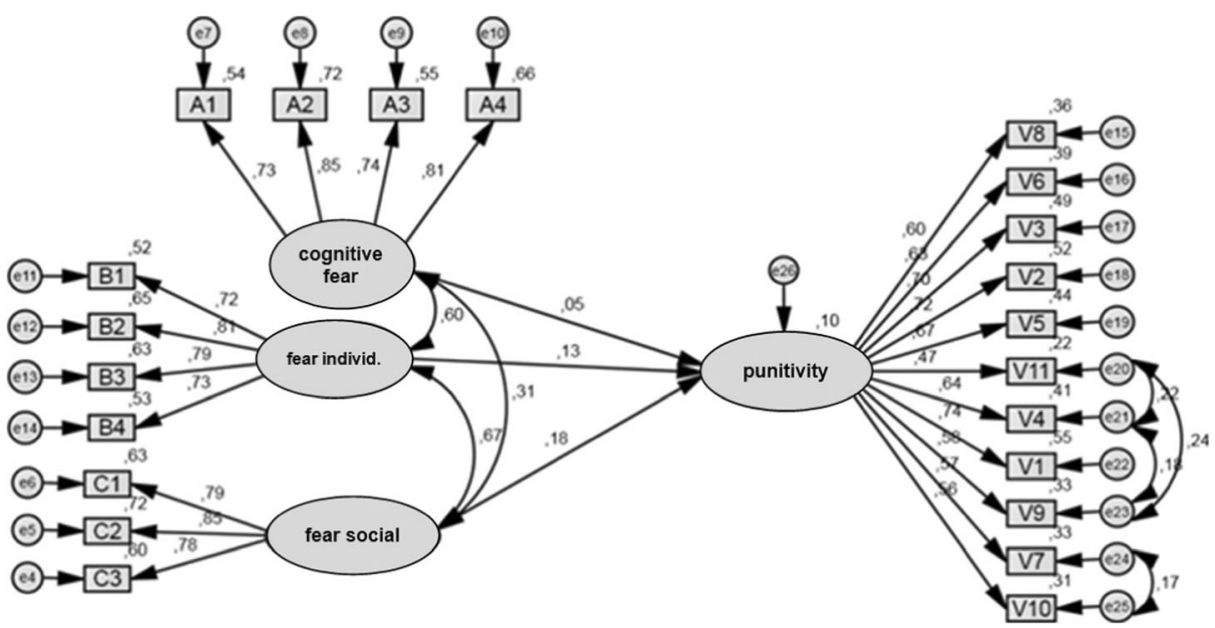

Fig. 2 SEM path diagram. RMSEA = .040; GFI = .944. For full indicator labels (V1-V11; A1-A4, B1-B4, C1C3) see Tables 1 and 5 . Values for indicator reliability $\left(\beta^{2}\right)$ in Tables 1 and 5 can slightly differ from those in Fig. 2

Table 6 summarizes how these characteristics moderate the correlation between the three types of fear of crime $\left(\boldsymbol{\beta}_{\mathrm{F} 1}-\boldsymbol{\beta}_{\mathrm{F} 3}\right)$ and the punitivity index. The influence of fear of crime on punitive attitudes as well as the overall explanatory power of the model varies depending on the four moderator variables.

Affective and cognitive fear of crime explain the extent of punitivity particularly well, when the respondent considers either deterrence $(\mathrm{AVE}=.19)$ or social rehabilitation $(\mathrm{AVE}=.22)$ the most important purpose of penal sanctions, but not so well if the respondent considers retribution $(\mathrm{AVE}=.05)$ the main purpose of punishment. Presumably, aversion to crime plays a role in forming punitive attitudes, if a respondent believes that criminal sanctions (both deterrent and rehabilitative) can actually prevent crime, and together with this their source of

Table 5 Means $(\overline{\mathrm{x}})$ of punitivity and fear of crime index

\begin{tabular}{|c|c|c|c|c|}
\hline$n=1172$ & & $\begin{array}{l}\bar{x} \\
\text { punitivity } \\
55.5\end{array}$ & $\begin{array}{l}\overline{\boldsymbol{x}} \text { fear offenses against } \\
\text { the general public } \\
33.7\end{array}$ & $\begin{array}{l}\overline{\boldsymbol{x}} \text { fear offenses } \\
\text { against the individual } \\
28.1\end{array}$ \\
\hline \multirow[t]{3}{*}{ Purpose of punishment } & Retribution (362) & 60.0 & 35.0 & 29.1 \\
\hline & Deterrence (342) & 61.2 & 36.0 & 28.0 \\
\hline & Rehabilitation (492) & 19.0 & 31.8 & 27.6 \\
\hline \multirow[t]{2}{*}{ Sex } & Male (618) & 56 & 34.8 & 26.1 \\
\hline & Female (654) & 54.8 & 32.8 & 30.5 \\
\hline \multirow[t]{3}{*}{ Age } & Under 30-40 (336) & 54.0 & 22.2 & 28.8 \\
\hline & $>40-60(470)$ & 55.0 & 32.7 & 26.4 \\
\hline & $>60$ and older $(450)$ & 57.0 & 44.5 & 30.2 \\
\hline \multirow[t]{3}{*}{$\begin{array}{l}\text { Highest formal } \\
\text { education }\end{array}$} & $\begin{array}{l}\text { None/lower secondary } \\
\text { (360) }\end{array}$ & 62.0 & 40.2 & 30.0 \\
\hline & Higher secondary (373) & 58.7 & 35.3 & 27.2 \\
\hline & $\begin{array}{l}\text { Tech. college/university } \\
\text { (443) }\end{array}$ & 46.0 & 26.6 & 28.0 \\
\hline
\end{tabular}


Table 6 Moderation

\begin{tabular}{|c|c|c|c|c|c|c|c|}
\hline \multirow{2}{*}{ Total } & & \multirow{2}{*}{$\begin{array}{l}\beta_{\text {F1 }} \\
.05 \text { n.s. }\end{array}$} & \multirow{2}{*}{$\begin{array}{l}\beta_{\mathrm{F} 2} \\
.13^{*}\end{array}$} & \multirow{2}{*}{$\begin{array}{l}\beta_{\mathbf{F 3}} \\
.18 * *\end{array}$} & \multirow{2}{*}{$\begin{array}{l}\bar{x} \text { PUN } \\
55.5\end{array}$} & \multirow{2}{*}{$\begin{array}{l}\text { AVE } \\
.10\end{array}$} & \multirow{2}{*}{$\begin{array}{l}\mathbf{n} \\
1272\end{array}$} \\
\hline & & & & & & & \\
\hline \multirow[t]{3}{*}{ Purpose of punishment } & Retribution & -.08 n.s. & $.14 *$ & $.15 * * *$ & 60.0 & .05 & 362 \\
\hline & Deterrence & $.08 *$ & .12 n.s. & $31 * * *$ & 61.2 & .19 & 342 \\
\hline & Rehabilitation & .05 n.s. & $.21 *$ & $.27 * * *$ & 19.0 & .22 & 492 \\
\hline \multirow[t]{2}{*}{ Sex } & Male & .03 n.s. & .12 n.s. & $.22 * * *$ & 56 & .11 & 618 \\
\hline & Female & - .07 n.s. & $.28 * * *$ & .10 n.s. & 54.8 & .11 & 654 \\
\hline \multirow[t]{3}{*}{ Age } & Under $30-40$ & $.47 * * *$ & -.08 n.s. & .09 n.s. & 54.0 & .21 & 336 \\
\hline & $>40-60$ & $-.23 * * *$ & $.48 * * *$ & -.11 n.s. & 55.0 & .13 & 470 \\
\hline & $>61$ and older & .01 n.s. & -.04 n.s. & $.44 * * *$ & 57.0 & .18 & 450 \\
\hline \multirow[t]{3}{*}{ Highest formal education } & None/lower secondary & $-.18 * * *$ & $.20 * *$ & $.37 * * *$ & 62 & .20 & 360 \\
\hline & Higher secondary & $.28 * * *$ & $-.14 *$ & $.1 \mathrm{n} . \mathrm{s}$. & 58.7 & .06 & 373 \\
\hline & Tech. college/university & $.15 * *$ & $.34 * * *$ & $.13^{* *}$ & 46.0 & .28 & 443 \\
\hline
\end{tabular}

F1: cognitive fear of crime

F2: affective fear of crime (individual);

F3: affective fear of crime (social)

n.s. not significant $* .05 * * .01 * * * .001$

fear. If the respondent regards criminal sanctions as a form of retribution fear of crime has almost no power to explain levels of punitivity (5\% explained variance).

Fear of crime plays a more significant role in the formation of punitive attitudes for respondents with a high (higher secondary school degree) and low level (lower secondary degree) of formal education, compared to respondents with an intermediate level of school education (technical college). Correspondingly, the proportion of explained variance for these groups is also relatively high or low, respectively. Fear of crime explains the rejection of tougher sanctions among respondents with higher secondary education $(\overline{\boldsymbol{x}}$ PUN $=46.0$ with $28 \%$ explained variance), and the endorsement of tougher sanctions among respondents with lower secondary education ( $\overline{\boldsymbol{x}}$ PUN $=62$ with $20 \%$ explained variance), but not the extent of punitivity of respondents with an intermediate level of formal education $(6 \%$ explained variance).

The suggestion that individual (F2) and social (F3) fear of crime work in different ways in the formation of punitive attitudes is best illustrated when one compares men and women. Social fear of crime is a significant predictor for punitive opinions of men $\left(\beta_{\mathbf{F} 3}=.22\right)$, but not of women. Oppositely, individual fear of crime is a significant predictor for punitive opinions of women $\left(\beta_{\mathbf{F} 2}=.28\right)$ but not for men. However, for both men and women, aversive emotions toward crime equally contribute to explaining their respective punitive attitudes (11\%), however in very different ways.

\section{Conclusions}

Different emotional and cognitive responses to crime have a distinctive effect on the formation of punitive attitudes, and these effects vary considerably depending on other factors. In this sample, anger about crime does not constitute a distinct emotional response to the perception of crime as a social problem or an individual thread. Therefore anger and fear cannot evoke different opinions about criminal punishment but must be operationalized as a single factor that 
simply represents aversion against crime. Crime aversion is clearly separable in regard to two different types of crimes, and each type has a distinctive effect on the formation of punitive attitudes, in particular when comparing men and women.

Men and women are almost equally punitive in their attitudes, but punitivity of men and women relate to fear of crime in different ways. Social fear of crime is a significant predictor for punitive opinions of men, but not of women. Oppositely, individual fear of crime is a significant predictor for punitive opinions of women but not for men. A plausible explanation is that punitivity might be an expression of the desire to control events that lie outside people's locus of control (Rotter 1966). Men are more fearful about crime against the general public $(\overline{\boldsymbol{x}}$ $=34.8)$ than women $(\overline{\boldsymbol{x}}=32.8)$ and less fearful in regard to individual victimization $(\overline{\boldsymbol{x}}=26.1)$ than women $(\overline{\boldsymbol{x}}=30.5) .{ }^{14}$ In accordance to the vulnerability thesis men, unlike women, might be under the impression that they can personally control individual victimization and therefore they do not "need" and consequently do not promote harsher sentences as a means to control this threat. Women might experience more helplessness in regard to individual victimization than men, and are therefore more likely to rely on criminal punishment as a means to control events outside their locus of control. Men might perceive crimes against the general public outside their locus of control, and therefore more heavily rely on punitive measures as an appropriate way to control this treat. Women presumably also experience a lack of control over crimes against the general public, but because they express less fear in regard to this type of crime (compared to men and compared to individual victimization) they do not feel a desire to control this event through harsher punishments. It seems that locus of control has a twofold impact on the formation of punitive attitudes: first via the described path of fear of crime, and second via the attribution style of delinquent behavior. A study of Maruna and King (2009) demonstrated that people who assume internal locus of control for criminal behavior tend to be more punitive than people who assume external locus of control. This conclusion can be a point of departure for future research.

However, not only gender moderates the influence of fear of crime on punitivity. Most notably fear of crime explains levels of punitivity particular well, when people believe that criminal sanctions can prevent crime either through deterrence or through rehabilitation.

In regard to the secondary (methodological) objective, this article found that punitivity is not the distinct and coherent attitudinal pattern that it is often assumed to be. The methodological challenges of this study raise important questions about the nature of punitive attitudes. In this particular survey, punitive attitudes were less consistent than observed in other studies. This is likely due to the methodical rigor of CFA, which, compared to EFA, requires more statistical coherence in the data in order to confirm the presence of a theoretical concept. In our study this coherence is given only to a limited degree. From this we conclude, that punitivity might be an academically overloaded concept that attracts a lot of scholarly attention despite the fact that it is a relatively indistinct attitudinal pattern. An alternative conclusion is that punitivity is indeed a robust attitudinal pattern, but that we do yet not know how to measure it.

Academic discussion aside; what are the real-world implications of this study? Both fear of crime and public opinion about criminal justice are of concern to policy makers and criminal justice practitioners. Populist movements in Europe know how to take advantage of these sentiments. Therefore, it is more important than ever to take these sentiments seriously. The

\footnotetext{
${ }^{14}$ As can be seen in Table 6 women $(\overline{\boldsymbol{x}}=30.5)$ express more individual fear of crime than men do $(\overline{\boldsymbol{x}}=26.1)$. This result should be interpreted with great caution. In a Scottish survey Sutton and Farrall (2005) found evidence that men to a greater extent than women underreport fear of crime due to social desirability.
} 
often technical and lengthy discussion of this article is one piece in the mosaic of evidence based practice in criminal policy.

Finally, there are important limitations to this study: the first is the issue of omitted variable bias. Of all potential factors that moderate the relation between emotional responses to crime and opinions about criminal policy this study includes only sex, level of education, age, and assumed purposes of punishment. Media consumption is a moderator variable in the interplay between fear of crime and punitive opinions, that was omitted from the model (Roche et al. 2016; Windzio et al. 2007; Pfeiffer et al. 2004). Another limitation is that a test of causal relation between fear of crime and punitivity is not possible with the cross-sectional data of this survey. To test, for instance, the hypothesis that perceived risk is an antecedent to emotional risk (Jackson 2011, Warr 1987 ) is not feasible within the scope of this study. By the same token the problem of collider variables and over-control bias (Elwert and Winship 2014) cannot be ruled out.

Open Access This article is distributed under the terms of the Creative Commons Attribution 4.0 International License (http://creativecommons.org/licenses/by/4.0/), which permits unrestricted use, distribution, and reproduction in any medium, provided you give appropriate credit to the original author(s) and the source, provide a link to the Creative Commons license, and indicate if changes were made.

\section{References}

Adriaenssen, A., \& Aertsen, I. (2015). Punitive attitudes: Towards an operationalization to measure individual punitivity in a multidimensional way. European Journal of Criminology, 12, 92-112.

Applegate, B. K., Cullen, F. T., Turner, M. G., et al. (1996). Assessing public support for three-strikes-andYou're-out Laws: Global versus specific attitudes. Crime \& Delinquency, 42, 517-534 .

Bagozzi, R. P. (1981). Evaluating structural equation models with unobservable variables and measurement error: A comment. Journal of Marketing Research, 18, 375-381.

Baker, T., Metcalfe, C. F., Berenblum, T., Aviv, G., \& Gertz, M. (2015). Examining public preferences for the allocation of resources to rehabilitative versus punitive crime policies. Criminal Justice Policy Review, 26, 448-462.

Birkel, C., et al. (Eds.). (2016). Opfererfahrung und kriminalitätsbezogene Einstellungen in Deutschland. Wiesbaden: Bundeskriminalamt.

Boers, K. (1991). Kriminalitätsfurcht - Über den Entstehungszusammenhang und die Folgen eines sozialen. Problems, Pfaffenweiler: Centaurus.

Bouton RA and et al. (1987). Scales for measuring fear of AIDS and homophobia. Journal of Personality Assessment 51, 606-614.

Browne, M. W. (1982). Covariance structures. In D. M. Hawkins (Ed.), Topics in applied multivariate analysis (pp. 72-141). Cambridge: Cambridge University Press.

Browne, M. W. (1984). Asymptotically distribution-free methods for the analysis of covariance structures. British Journal of Mathematical and Statistical Psychology, 37, 62-83.

Butter, R., Hermanns, J., \& Menger, A. (2013). Simultaneous prediction of punitive and rehabilitation-oriented attitudes towards probation: An ecological approach. Probation Journal, 60, 24-39.

Byrne, B. (2010). Structural equation modelling. New York: Routledge.

Chin, W. W. (1998). The partial least squares approach to structural equation modeling. In G. A. Marcoulides (Ed.), Modern methods for business research. New York: Psychology Press.

Chiricos, T., Welch, K., \& Gertz, M. (2004). Racial typification of crime and support for punitive measures. Criminology, 42, 358-390.

Cochran, J. C., \& Piquero, A. R. (2011). Exploring sources of punitiveness among German citizens. Crime \& Delinquency, 57, 544-571.

Cohen, P., Cohen, J., Aiken, L. S., et al. (1999). The problem of units and the circumstance for POMP. Multivariate Behavioral Research, 34, 315-346.

Costello, M. T., Chiricos, T., \& Gertz, M. (2009). Punitive attitudes toward criminals: Exploring the relevance of crime salience and economic insecurity. Punishment \& Society, 11, 25-49.

Costelloe, M. T., et al. (2002). The social correlates of punitiveness toward criminals: A comparison of the Czech Republic and Florida. Justice System Journal, 23, 191-220.

Ditton, J., Bannister, J., Gilchrist, E., et al. (1999). Afraid or angry? Recalibrating the 'fear' of crime. International Review of Victimology, 6, 83-99. 
Dowler, K. (2003). Media consumption and public attitudes toward crime and justice: The relationship between fear of crime, punitive attitudes, and perceived police effectiveness. Journal of Criminal Justice and Popular Culture, 10, 109-126.

Elwert, F., \& Winship, C. (2014). Endogenous selection bias: The problem of conditioning on a collider variable. Annual Review of Sociology, 40, 31-53.

Farrall, S. (2004). Revisiting crime surveys: Emotional responses without emotions? OR look back at anger. International Journal of Social Research Methodology, 7, 157-171.

Farrall, S., Jackson, J., \& Gray, E. (2009). Social order and the fear of crime in contemporary times. Oxford: Oxford University Press.

Fornell, C., \& Larcker, D. F. (1981). Evaluating structural equation models with unobservable variables and measurement error. Journal of Marketing Research 18, 39-50.

Frevel, B. (2003). Polizei, Politik und Medien und der Umgang mit dem bürgerschaftlichen Sicherheitsgefühl. In H. J. Lange (Ed.), Die Polizei der Gesellschaft (pp. 321-336). Wiesbaden: VS Verlag für Sozialwissenschaften.

Garland, D. (2000). The Culture of high crime societies. Journal of Criminology, 40, 347-375.

Garland, D. (2001). The Culture of control. Oxford: Oxford University Press.

Garland, B., Wodahl, E., Smith, R. G. (2015). Religious beliefs and public support for prisoner reentry. Criminal Justice Policy Review, 1-17.

Gray, E., Jackson, J., \& Farrall, S. (2008). Reassessing the fear of crime. European Journal of Criminology, 5, $363-380$.

Gray, E., Jackson, J., \& Farrall, S. (2012). In search of the fear of crime. In D. Gadd, S. Karstedt, \& S. F. Messner (Eds.), Sage handbook of criminological research methods. London: Sage.

Hair, J. F. (2006). Multivariate data analysis. Upper Saddle River: Prentice Hall.

Hamilton, C. (2014). Reconceptualizing penalty. Towards a multidimensional measure of punitiveness. British Journal of Criminology, 54(2), 321-343.

Hartnagel, T. F., \& Templeton, L. J. (2012). Emotions about crime and attitudes to punishment. Punishment \& Society, 14, 452-474.

Haverkamp, R., Hummelsheim, D., \& Armborst, A. (2013). Studien zur Sicherheit in Deutschland. Yearbook of the max Planck Society. München: Max Planck Society.

Hirtenlehner, H. (2006). Kriminalitätsfurcht — Ausdruck generalisierter Ängste und schwindender Gewissheiten? Kölner Zeitschrift für Soziologie und Sozialpsychologie, 58, 307-331.

Hirtenlehner, H. (2011). The origins of punitive mentalities in late modern societies. In H. Kury \& E. Shea (Eds.), Punitivity. International Developments (pp. 27-51). Bochum: Universitätsverlag Dr. N. Brockmeyer.

Hogan, M. J., Chiricos, T., \& Gertz, M. (2005). Economic insecurity, blame, and punitive attitudes. Justice Quarterly, 22, 392-412.

Hough, M., Bradford, B., Jackson, J., Roberts, J. V. (2013). Attitudes to sentencing and trust in justice: Exploring trends from the crime survey for England and Wales. Ministry of Justice analytical series. London: Ministry of Justice.

Hummelsheim, D., Hirtenlehner, H., Jackson, J., et al. (2011). Social insecurities and fear of crime: A crossnational study on the impact of welfare statepolicies on crime-related anxieties. European Sociological Review, 27(3), 327-345.

Jackson, J. (2005). Validating new measures of the fear of crime. International Journal of Social Research Methodology, 8, 297-315.

Jackson, J. (2011). Revisiting risk sensitivity in the fear of crime. Journal of Research in Crime and Delinquency, $48,513-537$.

Johnson, D. (2009). Anger about crime and support for punitive criminal justice policies. Punishment \& Society, $11,51-66$.

Karstedt, S. (2002). Emotions and criminal justice. Theoretical Criminology, 6, 299-317.

Karstedt, S., Loader, I., \& Strang, H. (2011). Emotions, crime and justice. Oxford: Hart.

King, A., \& Maruna, S. (2009). Is a conservative just a liberal who has been mugged? Punishment \& Society, 11, 147-169.

Kleck, G. and Jackson, D.B. (2016). Does crime cause punitiveness? Crime \& Delinquency. doi: 10.1177 $/ 0011128716638503$.

Klimke, D., Sack, F., \& Schlepper, C. (2011). Stopping the 'punitive turn' at the German border. In H. Kury \& E. Shea (Eds.), Punitivity. International Developments (pp. 289-340). Bochum: Universitätsverlag Dr. N. Brockmeyer.

Kury, H. (2008). Fear of crime - Punitivity. New Developments in theory and research. Bochum: Brockmeyer.

Kury, H., \& Obergfell-Fuchs, J. (2008). Methodische Probleme bei der Erfassung von Sanktionseinstellungen. In A. Groenemeyer \& S. Wieseler (Eds.), Soziologie sozialer Probleme und sozialer Kontrolle (pp. 231-255). VS Verlag für Sozialwissenschaften: Wiesbaden.

Kury, H., \& Winterdyk, J. (2013). Fear of crime and Punitiveness; results from international student surveys. Bochum: Brockmeyer. 
Kury, H., Kania, H., \& Obergfell-Fuchs, J. (2004). Worüber sprechen wir, wenn wir über Punitivität sprechen? Kriminologisches Journal, 8, 51-88.

Langworthy, R. H., \& Whitehead, J. T. (1986). Liberalism and fear as explanations for Punitiveness. Criminology, 24, 575-591.

Lautmann, R., \& Klimke, D. (2004). Punitivität als Schlüsselbegriff für eine Kritische Kriminologie. Kriminologisches Journal, 36, 9-29.

Maguire, E., \& Johnson, D. (2015). The structure of public opinion on crime policy: Evidence from seven Caribbean nations. Punishment \& Society, 17, 502-530.

Mardia, K. V. (1970). Measures of multivariate skewness and kurtosis with applications. Biometrika, 57, 519530.

Maruna, S., \& King, A. (2009). Once a criminal, always a criminal?: 'Redeemability' and the Psychology of punitive public attitudes. European Journal on Criminal Policy Research, 15, 7-27.

Mascini, P., \& Houtman, D. (2006). Rehabilitation and repression: Reassessing their ideological embeddedness. British Journal of Criminology, 46(5), 822-836.

Messner, S., Baumer, E. P., \& Rosenfeld, R. (2006). Distrust of government, the vigilante tradition, and support for capital punishment. Law \& Society Review, 40, 559-590.

Moser, S. C. (2007). More bad news: The risk of neglecting emotional responses to climate change information. In S. Moser \& L. Dilling (Eds.), Creating a climate for change. Cambridge: Cambridge University Press.

Oberwittler, D. (2008). Armut macht Angst — Ansätze einer sozialökologischen Interpretation der Kriminalitätsfurcht. In A. Groenemeyer \& S. Wieseler (Eds.), Soziologie sozialer Probleme und sozialer Kontrolle (pp. 215-230). VS Verlag für Sozialwissenschaften: Wiesbaden.

Payne, B. K., Gainey, R. R., Triplett, R. A., et al. (2004). What drives punitive beliefs?: Demographic characteristics and justifications for sentencing. Journal of Criminal Justice, 32, 195-206.

Pfeiffer, C., Windzio, M., \& Kleimann, M. (2004). Die Medien, das Böse, und wir. Zu den Auswirkungen der Mediennutzung auf Kriminalitätswahrnehmung, Strafbedürfnisse und Kriminalpolitik. Monatsschrift für Kriminologie und Strafrechtsreform, 88, 415-436.

Pickett, J. T., \& Baker, T. (2014). The pragmatic American: Empirical reality or methodological artifact? Criminology, 52, 195-222.

Pratt, J. (2000). Sex crimes and the new punitiveness. Behavioral Sciences \& the Law, 18, 135-151.

Pratt, J. (2007). Penal Populism. London: Routledge.

Pritsch, J., \& Oberwittler, D. (2016). Kriminalitätsfurch in Deutschland - Kontexteffekte auf ein individuelles Empfinden. In C. Birkel et al. (Eds.), Opfererfahrung und kriminalitätsbezogene Einstellungen in Deutschland. Bundeskriminalamt: Wiesbaden.

Qi, S, Oberwittler, D. (2009). Public Opinion on the Death Penalty in China. Results from a general population survey conducted in three provinces in 2007/08. Research in Brief 41, Max Planck Institute for Foreign and International Criminal Law.

Raykov, T., \& Marcoulides, G. A. (2006). A first course in structural equation modeling. New York: Lawrence Erlbaum Associates.

Reichert A, Tauchmann H. (2011). The causal impact of fear of unemployment on psychological health. Ruhr Economic Papers. 266, 1-28.

Reuband, K.-H. (1980). Sanktionsverhalten im Wandel. Kölner Zeitschrift für Soziologie und Sozialpsychologie, $32,535-558$.

Reuband, K.-H. (2007a). Changing punitiveness in the German population? A review of the empirical evidence based on nationwide surveys. In H. Kury \& E. Shea (Eds.), Punitivity international developments vol. 2: insecurity and punitiveness. Bochum: Universitätsverlag Dr Brockmeyer.

Reuband, K.-H. (2007b). Konstanz und Wandel in der "Strafphilosophie" der Deutschen - Ausdruck stabiler Verhältnisse oder steigender Punitivität? Ergebnisse eines Langzeitvergleichs (1970-2003). Soziale Probleme, 18, 186-213.

Reuband, K. -H. (2011). Changing punitiveness in the German population? A review of the empirical Evidence based on nationwide surveys. In H. Kury \& E. Shea (Eds.), Punitivity international developments vol. 2 : insecurity and punitiveness (pp. 131-163). Bochum: Universitätsverlag Dr. Brockmeyer.

Roche, S. P., Pickett, J. T., \& Gertz, M. (2016). The scary world of online news? Internet news exposure and public attitudes toward crime and justice. Journal of Quantitative Criminology, 32, 215-236.

Rotter, J. B. (1966). Generalized expectancies for internal versus external control of reinforcement. Psychological Monographs: General and Applied, 80(1), 1-28.

Schmitt, N. (1996). Uses and abuses of coefficient alpha. Psychological Assessment, 8, 350-353.

Sessar, K. (2010). Kriminalitätseinstellungen und sozialer Wandel. Monatsschrift für Kriminologie und Strafrechtsreform, 93, 361-381.

Simonson, J. (2011). Problems in measuring punitiveness - results from a German study. In H. Kury \& E. Shea (Eds.), Punitivity. Bochum: Universitätsverlag Dr. N. Brockmeyer. 
Spiranovic, C. A., Roberts, L. D., \& Indermaur, D. (2011). What predicts Punitiveness? An examination of predictors of punitive attitudes towards offenders in Australia. Psychiatry, Psychology and Law, 19, 249261.

Steiger, J. H. (1990). Structural model evaluation and modification: An interval estimation approach. Multivariate Behavioral Research, 25, 173-180.

Sutton, R. M., \& Farrall, S. (2005). Gender, socially desirable responding and the fear of crime. Are women really more anxious about crime? British Journal of Criminology, 45(2), 212-224.

Tyler, T. R., \& Boeckmann, R. J. (1997). Three strikes and you are out, but why? The Psychology of public support for punishing rule breakers. Law \& Society Review, 31, 237-265.

Vanderveen, G. (2008). How to measure "fear of crime" in a valid and reliable way? In H. Kury \& E. Shea (Eds.), Fear of crime - punitivity. New developments in theory and research (pp. 33-52). Bochum: Universitätsverlag Dr. N. Brockmeyer.

Warr, M. (1987). Fear of victimisation and sensitivity to risk. Journal of Quantitative Criminology, 3, $29-46$.

Warr, M. (1992). Altruistic fear of victimization in households. Social Science Quarterly, 73, 723-736.

Windzio, M., Simonson, J., Pfeiffer, C., Kleimann, M. (2007). Kriminalitätswahrnehmung und Punitivität in der Bevölkerung - Welche Rolle spielen die Massenmedien? Forschungsbericht. Hannover: KFN.

Wothke, W. (1993). Nonpositive definite matrices in structural modeling. In K. A. Bollen \& J. S. Long (Eds.), Testing structural equation models. Newbury Park: Sage.

Zimring, F. E., \& Johnson, D. T. (2006). Public opinion and the governance of punishment in democratic political systems. The Annals of the American Academy of Political and Social Science, 605, 265-280. 